\title{
THE ECONOMIC FUTURE JUST HAPPENED
}

Dane Stangler

Ewing Marion Kauffman Foundation

June 9, 2009

Ewing Marion

KAUFFMAN

Foundation 


\title{
THE ECONOMIC FUTURE JUST HAPPENED
}

\author{
Dane Stangler \\ Ewing Marion Kauffman Foundation
}

June 9, 2009

\section{Contributors}

Brian Higginbotham (George Mason University)

Paul Kedrosky (Ewing Marion Kauffman Foundation)

Robert Litan (Ewing Marion Kauffman Foundation)

E.J. Reedy (Ewing Marion Kauffman Foundation)

Carl Schramm (Ewing Marion Kauffman Foundation)

\author{
Ewing Marion \\ KAUFFMAN \\ Foundation
}

(C) 2009 by the Ewing Marion Kauffman Foundation. All rights reserved. 


\section{Introduction}

Amid the worst economic contraction since 1981-82, and possibly the Great Depression, attention has naturally turned toward the silver lining we might be able to find around the gloom. Some have turned toward historical work on the Great Depression, noting the bright spots that existed; others have examined the relationship, if any, between recessions and entrepreneurial activity. ${ }^{1}$ By peering into the economic past, we hope to somehow circumvent our very limited prognosticative abilities and answer the question, "What effect do recessions have on new firm formation?"

This research study, analyzing data from the U.S. Census, the Fortune 500, and the Inc. list of America's fastest-growing companies, presents three main findings:

1. Recessions and bear markets, while they bring pain and often lead to short-term declines in business formation, do not appear to have a significantly negative impact on the formation and survival of new businesses.

2. Well-over half of the companies on the 2009 Fortune 500 list, and just under half of the $2008 \mathrm{Inc}$. list, began during a recession or bear market. We also find that the general pattern of founding years and decades can help tell a story about larger economic trends.

3. Job creation from startups is much less volatile and sensitive to downturns than job creation in the entire economy.

While these data are far from conclusive and can only hint at broader trends, they do illustrate a more fundamental economic reality: each year, new firms steadily recreate the economy, generating jobs and innovations. These companies may be invisible, or they may one day grow into household names. But they constantly come into being as individuals bring forth their economic futures.

\section{The Entrepreneurial Response to Recessions}

It might be expected that economic contractions would suppress, at least in the immediate run, the number of new companies founded each year. If we look at

\footnotetext{
${ }^{1}$ Recent discussions have recalled Alexander Field's American Economic Review article from six years ago calling the 1930s the most "technologically progressive" decade of the twentieth century: http://www.marginalrevolution.com/marginalrevolution/2009/03/the-most-technologicallyadvanced-decade-of-the-20th-century.html. See also Alexander J. Field, "The Most Technologically Progressive Decade of the Century," 93 American Economic Review 1399 (Nov. 2003).

${ }^{1}$ e.g., Paul Kedrosky, "Entrepreneurs and Recessions: Do Downturns Matter?" Kauffman Foundation Research Report, December 2008, at http://www.kauffman.org/uploadedFiles/ entrepreneurs and recessions 121508.pdf. For a look at a handful of successful companies begun during recessions, see http://www.inc.com/magazine/20080501/defyinggravity pagen $2 . \mathrm{html}$.
} 
data on new firms and new establishments over time ${ }^{3}$ including recessions, we see that this is indeed the case:

Figure 1

New Establishments and New Firms in Recessions (shaded areas)

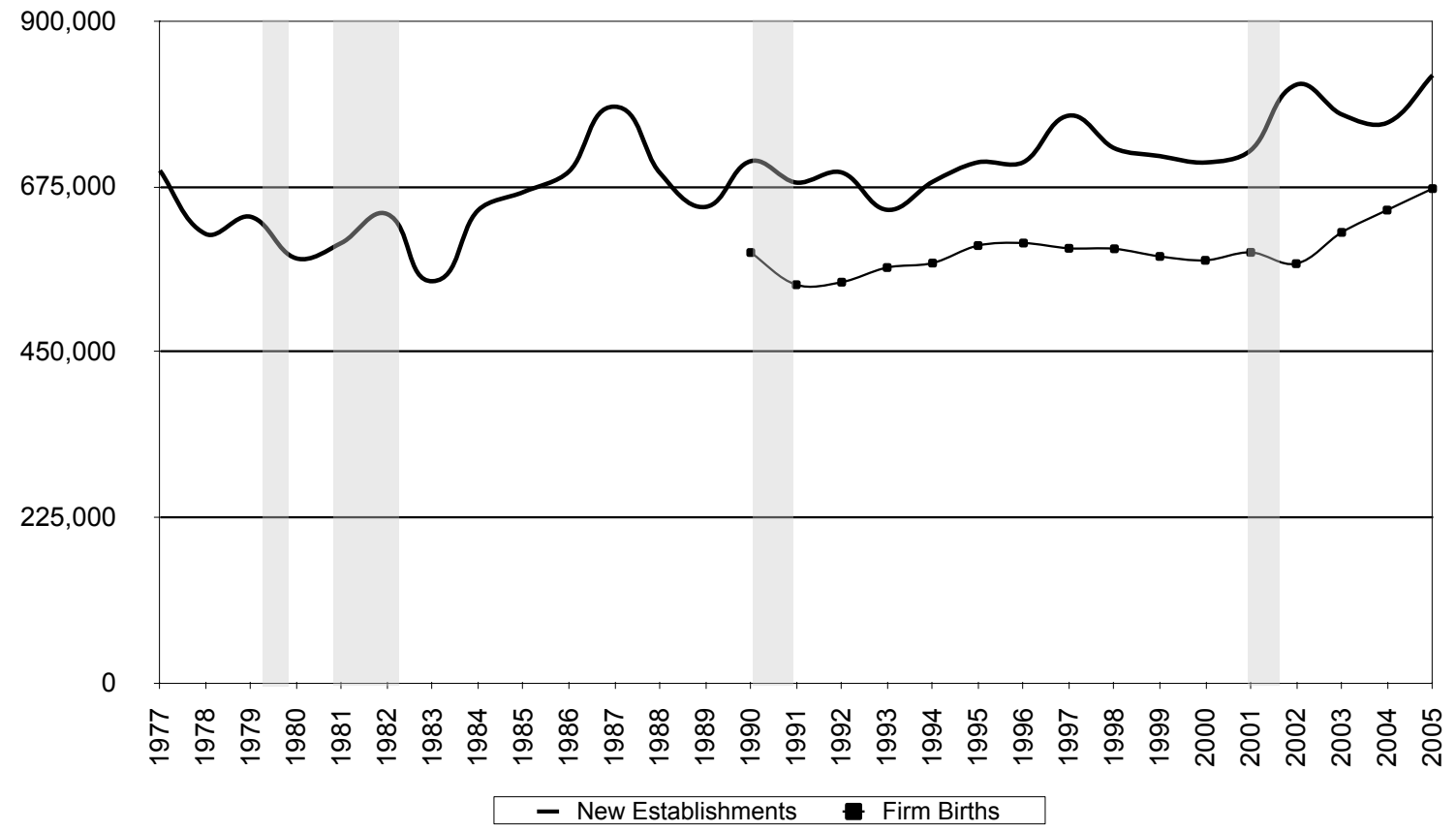

Sources: U.S. Census Bureau, Statistics of U.S. Business, http://www.census.gov/csd/susb/susbdyn.htm;

U.S. Census Bureau, Business Dynamics Statistics, http://www.ces.census.gov/index.php/bds.

New firm formation fell during the 1990-91 recession and from 2001-02 as well, but exceeded pre-recession levels within a couple of years. While the recessions of 1980, 1981-82, and 1990-91 led to dips in the number of new establishments, the numbers not only rebounded within a year or two, but the 2001 recession actually saw an increase in the number of new establishments. Downturns are not the only suppressive force: firm and establishment births also declined in the late 1990s, a period of expanding productivity, wages, and growth. (See the appendix for comparisons with productivity.) Comparing new establishments and bear markets, as well as the establishment entry rate against recessions, sheds no additional light (see appendix).

It is difficult to draw from these numbers alone sound conclusions concerning whether or not contractions matter to entrepreneurs. On the one hand, we might expect recessions or bear markets to suppress entrepreneurial activity: external financing (to the extent that new firms access it) might not be readily available. People might be less willing to leave a secure job; in general, the economy's "animal spirits" might be dampened all around.

\footnotetext{
${ }^{3}$ An "establishment" is a new location for an existing firm. Walmart, for example, is a single firm with several thousand establishments.
} 
On the other hand, there are good reasons to expect recessions and bear markets to be fertile periods for new firms and, possibly, their subsequent success. Although many new firms don't rely on external financing in their early stages ${ }^{4}$ a suppressed financial climate may be less immediately relevant to a person's propensity to found a new company versus the person's later ability to grow the company. Rising unemployment, because it is often concentrated among large or established companies, can free up pools of human capital in two ways. An unemployed individual, with some measure of experience (and, in some cases, a vested pension), may perceive a competitive opportunity to start a new company, and feel there's nothing to lose. ${ }^{5}$ Entrepreneurs may also target the unemployed as a potential pool of employees. The matter of longer-term success is a bit murkier-although there is some evidence that recession-era companies may end up slightly more successful, ${ }^{6}$ it remains an open question.

\section{Using Our Economic Past to Explore Our Future}

To get a better handle on these questions, and to begin to explore, as far as possible, the implications of the 2007-09 recession and bear market, we looked at two existing data sources, the Fortune and Inc. magazine lists of, respectively, the largest American companies and the fastest-growing companies. These permit the examination of relatively sizeable datasets across time, as well as the experiences of specific companies.

We began by assembling the founding dates of the companies on the 2009 Fortune list. In most cases, this is rather straightforward: a company began in a particular year. In some cases, however, the question of a firm's founding date is much more ambiguous because of mergers, direct or indirect ancestry, whether to date a founding from a first patent or incorporation, etc. For these questions, we used two sources. One was a previous analysis of Fortune 500 founding dates conducted in 19967; the other was consultation of a company's own Web site. When multiple founding dates appeared (across Fortune or financial information sites), we used the company's indication of the date to which it traces its history. ${ }^{8}$

\footnotetext{
${ }^{4}$ e.g. Alicia Robb, et al, "An Overview of the Kauffman Firm Survey: Results from the 2004-2007 Data," Kauffman Foundation, April 2009, http://www.kauffman.org/uploadedFiles/kfs fourth 040709.pdf.

${ }^{5} \mathrm{~A}$ boost may also come in the form of "necessity" entrepreneurship-a displaced worker opens his/her own business because it is his/her only option.

${ }^{6}$ Kedrosky, supra note 2.

7 Harris Corporation, "Founding Dates of the 1994 Fortune 500 U.S. Companies," Business History Review, Spring 1996, 69.

8 Due to irreconcilable findings or inability to verify a date, twelve companies from the Fortune 500 were excluded from final findings. The final sample, then, is 488 .
} 
Figure 2

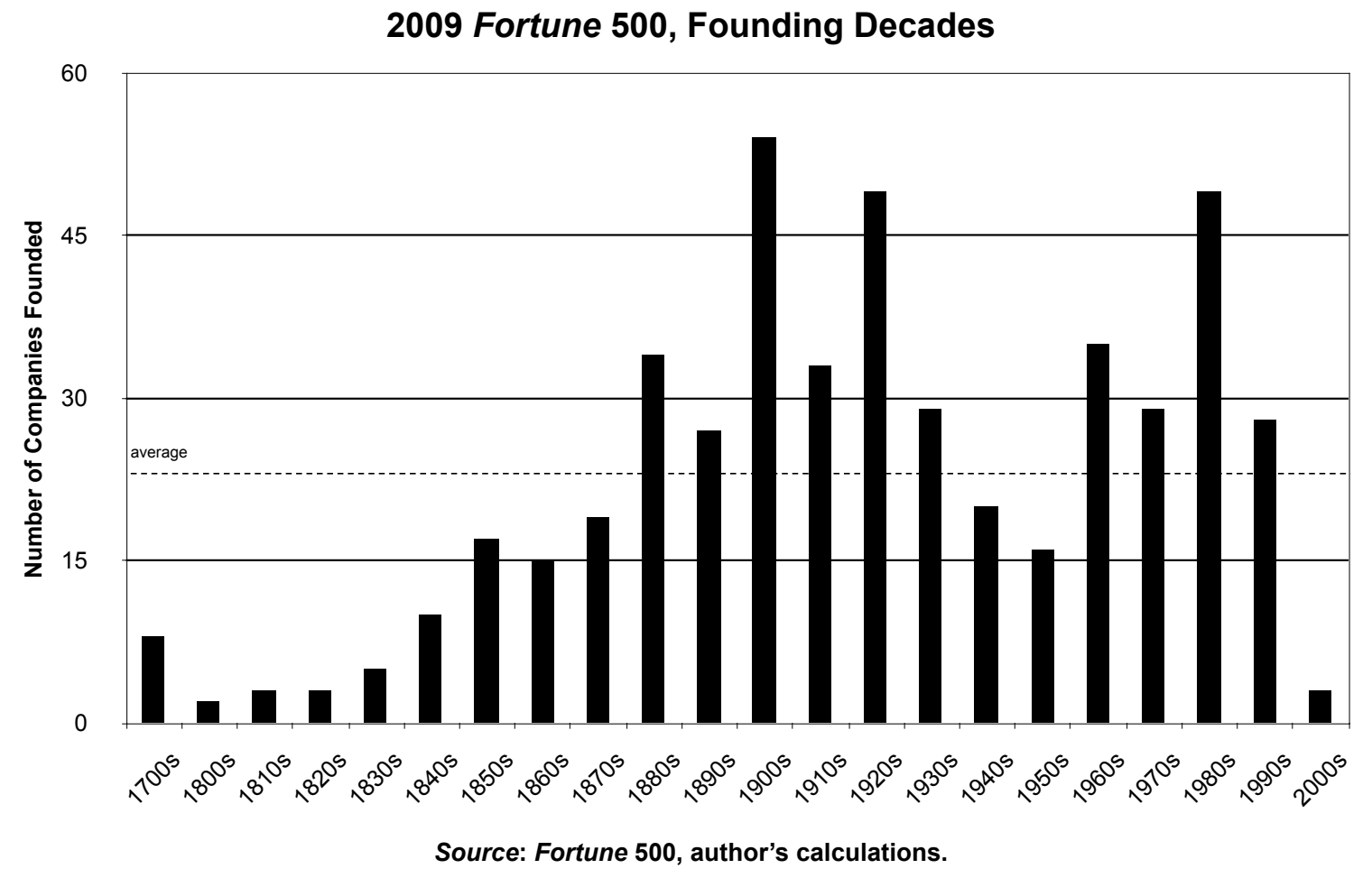

Once these dates were assembled, we compared them to the expansion and contraction dates of the National Bureau of Economic Research (NBER), official keeper of business cycles for the U.S. economy. ${ }^{9}$ Bear market dates, covering the period 1929-present, were taken from two sources. ${ }^{10}$

The conclusions concerning the Fortune 500 are somewhat surprising, to say the least. Of the 488 companies included in the final analysis, 256 or 51 percent, began during a recession or bear market or both. ${ }^{11}$ This, however, is an understatement: NBER business cycle dating begins in December 1854, and a number of companies, forty to be exact, trace their beginnings to pre-1855 years.

\footnotetext{
${ }_{9}^{9}$ NBER, Business Cycles and Expansions, http://www.nber.org/cycles.html.

${ }^{10} \mathrm{~A}$ bear market is commonly defined as a period of time during which a stock index, such as the Dow Jones Industrial Average or Standard \& Poor's 500, falls 20 percent or more. For graphs on bear market reference dates used in this paper, see "How This Bear Market Compares," New York Times, Oct. 11, 2008, http://www.nytimes.com/interactive/2008/10/11/business/ 20081011_BEAR_MARKETS.html, and JP Koning, Financial Graphs and Art, http://www.financialgraphart.com/public.html.
}

11 Of these 256, fifty-three were founded during a bear market only, meaning that 45 percent of our Fortune 500 sample were founded during recessions. We recognize that relying on the Fortune 500 list presents the issue of survivorship bias-one that potentially changes, moreover, from year to year. That is, looking only at the 500 largest companies in 2008 and their founding dates excludes all other firms that started in a given year, as well as the companies that were on the list in prior years but either fell off or disappeared altogether. A snapshot in 1978 or 1958 would obviously look different. For this reason, as will become clear, we tried to look as much as we could at new firm survival rates, and tried to be circumspect with our more general conclusions. 
Excluding these leaves a dataset of 448 Fortune 500 companies-of these, an extraordinary 57 percent were founded during a recession or bear market. ${ }^{12}$

What about the country's fastest-growing firms? Every year, Inc. magazine publishes a list of the 500 (expanded in recent years to 5,000) fastest-growing companies. To get a different perspective on the distribution of founding dates, we consulted the Inc. 500 lists for 1985 and $2008 . .^{13}$ In 1985, for the 372 companies that reported a founding date, 26 percent were founded during a recession, and 41 percent during a bear market. Thus, two-thirds of the companies began during a recession or bear market. ${ }^{14}$ In 2008 , each of the top 500 companies reported a founding date-only 17 percent were founded during a recession, while 31 percent began amid a bear market. This means nearly half of the 2008 Inc. originated in a recession or bear market. ${ }^{15}$

That well over half of the largest companies in the United States and close to half of the fastest-growing firms were founded during recessions or bear markets is, or should be seen as, remarkable. But does it tell us anything useful about our economic future beyond the current downturn? To address this, we calculated, again using the NBER business cycle dates, that from 1855 to 2002, the United States experienced a total of 544 months of contraction: 31 percent of the entire period. In other words, since 1855, we have been in periods of contraction roughly one-third of the time.

If we break this century and a half into segments, we see sometimes large differences. From 1855 to 1919, for example, the economy was in contraction just under half the time (45 percent); from 1919-1945, 33 percent. The postwar period has, by contrast, been dominated by expansion: the economy was contracting only 15 percent of this time. By simple probability, then, a company founded in the nineteenth century had a higher chance of being founded during a recession than one founded since World War II. This, of course, assumes that all recessions are more or less the same, which is likely not to be a valid assumption.

\footnotetext{
12 Two of the pre-1855 companies were founded in 1837, a year that experienced a significant financial panic. These were excluded from our total number of recession and bear market foundings.

13 Inc., http://www.inc.com/inc5000/2008/the-full-list.html.

${ }^{14}$ Compared to the Fortune list, the companies ranked by Inc. present a much narrower band of ages. The mean age of the 372 companies in 1985 was just under nine years, with a median of seven. The average Inc. firm, then, would have been founded either in 1976 or 1978, both bear market years.

15 The mean age of the 2008 top 500 was $7 \frac{1}{2}$, with a median of six, indicating that the average Inc. firm would have been founded in 2001, a recession year, or 2002, a bear market year. This makes it somewhat remarkable, then, that only eighty-three of the 500 firms were founded during a recession, with 2001 being the most common recessionary year. Note that we don't double count: a company founded in 2001 is counted as starting during a recession, notwithstanding that the bear market lasted from early 2000 into late 2002. Thus, we can combine the eighty-three firms founded during a recession with the 157 founded during a bear market to get the figure that 48 percent of the list was founded during either a recession or bear market.
} 
To even this out, we combined postwar recessions and bear markets: how often has the United States experienced recessions and/or bear markets since 1945? The answer: 43 percent of the time, a figure much more comparable to earlier eras. This, of course, also assumes that bear markets are somewhat equivalent in their economic effect to recessions, an assumption that may be less than sound. Furthermore, no company can have fully anticipated success, let alone known that it would later appear on the Fortune 500 list (which was only established in 1955 anyway). And, even when a firm began during a recession, there was probably uncertainty (with some exceptions), as to whether the country was in fact officially experiencing a contraction or whether, on the back end, it had emerged from an official contraction. Today, with all our sophisticated economic modeling tools, the recession that began in December 2007 was not officially called until a year after it had begun (although, to be fair, many publications, including Inc., had already concluded that the United States was in recession).

Nonetheless, the general analysis holds: over half of our largest companies began during a recession or bear market. The next step in the analysis is a bit more tenuous: surveying the years and decades during which today's Fortune 500 companies were founded, can we infer backward anything about those periods? That is, seeing that the first decade of the twentieth century boasts the most subsequent Fortune firms (54), does that allow us to say anything relative to other decades? Are there trends we can validly identify?

The prima facie fact that 1900-09 and the 1920s turn out to be two of the most common decades for future Fortune firms shouldn't be too surprising. Many of the industries that came to dominate the twentieth century, and (evidently) still play a large role today, emerged in that era. The late Joseph Schumpeter, the leading economist of entrepreneurship, based much of his economic and historical analysis on the first great period of entrepreneurial capitalism, the halfcentury from roughly 1880 up to the Great Depression, commonly referred to as the Second Industrial Revolution. Thus, companies like Sears (1886), General Electric (1892), 3M (1902), Ford (1903), Boeing (1916), State Farm Insurance (1922), and Delta Air Lines (1924) date from this era.

That years generally remembered as highly entrepreneurial and revolutionary should coincide with the founding dates of a number of still-successful companies is none too surprising. That this fifty-year period experienced contractions 41.5 percent of the time (including three rather severe downturns: 1893-94, 1896-97, 1920-21), is perhaps a bit surprising.

Looking at Figure 2, we can see that from the 1920s, there is a steady drop to the 1930s (predictably, perhaps), to the 1940s (again, predictably), and to the 1950s. This is followed by a spike in the 1960s, continued through the 1970 s and into the 1980s. Do these ups and downs allow us to generalize about the 
economy? Seeing that the 1930s display a drop compared to the previous few decades is, as indicated, to be expected. The Great Depression, lasting from late 1929 to early 1933, with lingering effects after that, followed by a recession in 1937-38, wouldn't indicate a particularly propitious time to start a company. Yet the decade turns out to be home to an above-average number of Fortune 500 companies (29; the average for all decades is 22), and if we look at the decade, we see that the recessionary years were stronger than the recovery years.

Figure 3

Fortune 500 Foundings in the 1930s

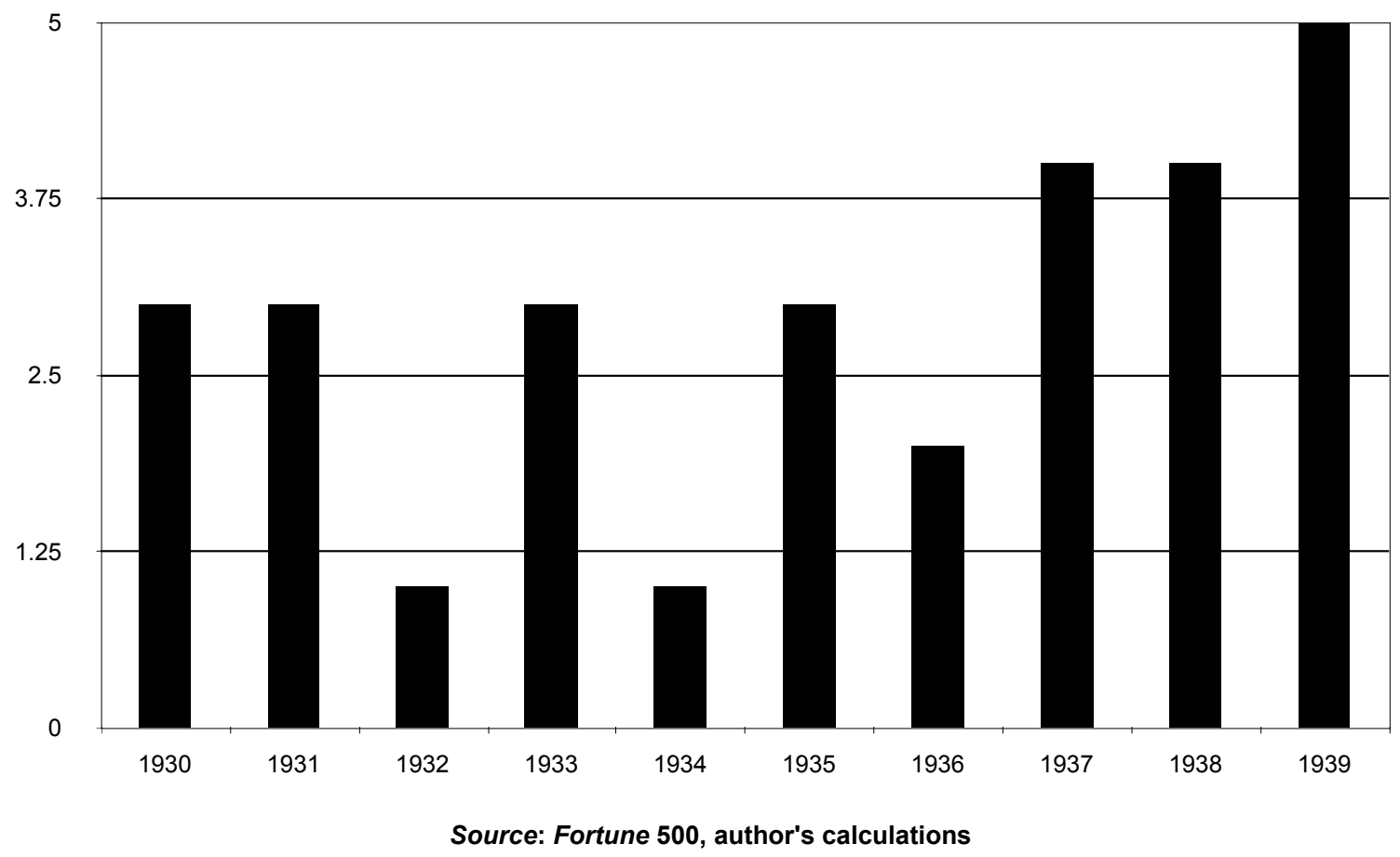

When compared, moreover, to subsequent decades, the 1930s stand out. We shouldn't be shocked to learn that the 1940s were an average decade (so much production during the first half of the decade was directed toward the war), but the 1950s jump out to any casual observer. Could it be that what is often perceived to be the high tide of bureaucratic capitalism-in which the entrepreneurial companies of the 1890s, 1900s, and 1920s grew to be industrial behemoths, supported by powerful labor unions and a government swollen by depression and war-actually did have a dampening effect on new firm formation? Historical statistics certainly suggest that, in the aggregate, firm 
formation in the 1950s lagged behind other decades. ${ }^{16}$ On its face, then, the low number of the 1950s appears to support the conventional story of the 1950's "organization man." There is some evidence, too, that during the 1950s, the U.S. financial sector was underdeveloped relative to earlier and later decades, a state of affairs that would tend to favor established, rather than new, companies. ${ }^{17}$

One way to test the relationship between the firm formation climate in any given year and the number of Fortune 500 firms that emerged is to look at the years for which we do have such information. In Figure 1, we charted the number of new establishments from 1977 to 2005; we can now compare that line to the number of Fortune firms founded each year.

Figure 4

Fortune 500 Foundings and New Establishments

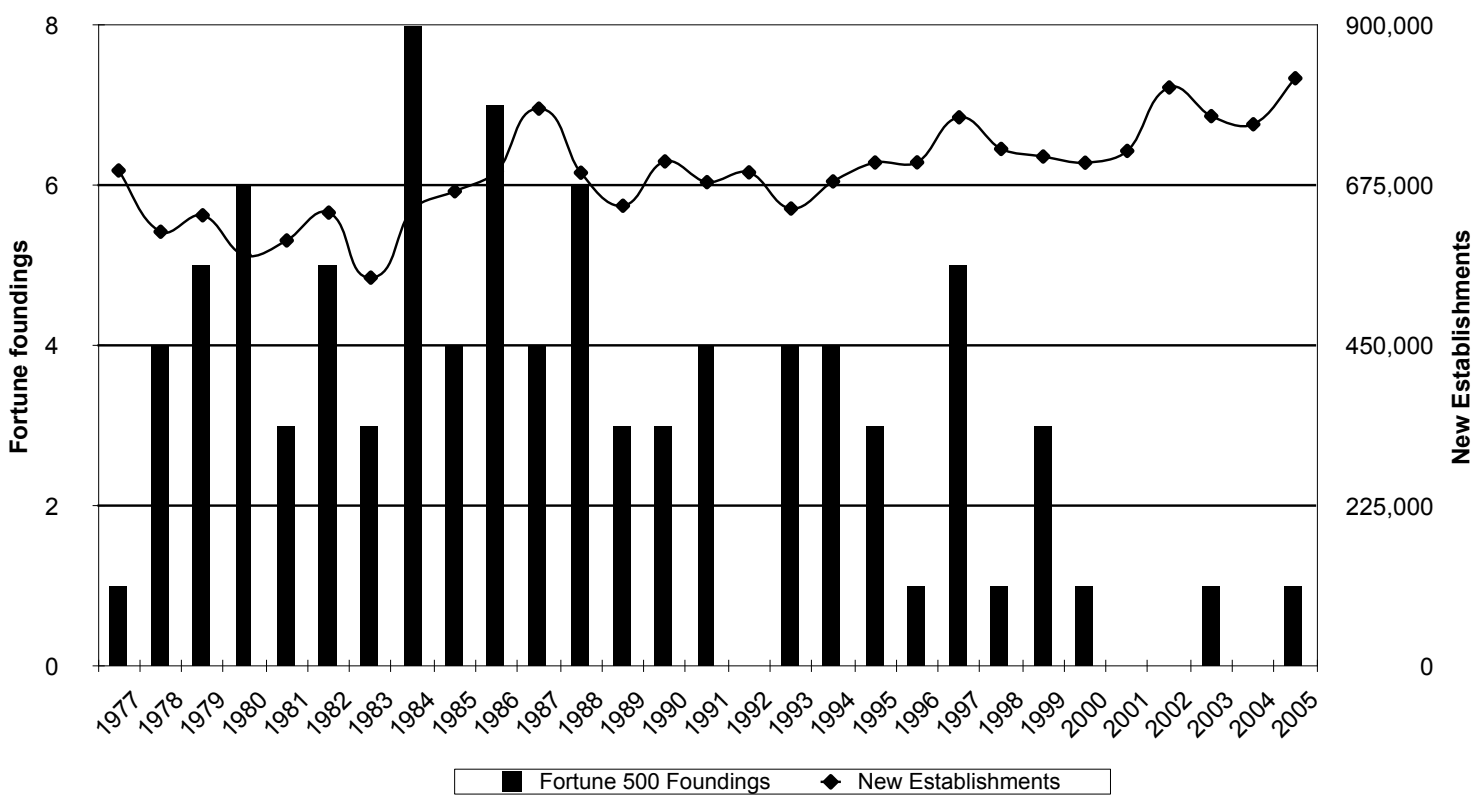

Source: Fortune 500, author's calculations; Census Bureau, http://www.ces.census.gov/index.php/bds/bds home.

16 In 1900, the number of firms per 1,000 in population stood at 15.4 , rising to 18.2 in 1929 and, by 1950 , held rather steady at 17.7. In ten years, however, the number fell to 14.99. George Thomas Kurian (ed.), Datapedia of the United States, 1790-2005: America Year by Year 7, 435 $\left(2^{\text {nd }}\right.$ ed., 2001). The number of new business started in the 1950 s averaged 385,000 a year, compared to 441,000 a year from 1944 to 1949 . There was a burst of new business formation, not surprisingly, in 1946, after years of war and depression-a 75 percent increase over 1944. No year in the 1950s approached the average number of new businesses started from 1944-1949 and, if we're tempted to read backward from the numbers, the late 1940s also produced more Fortune firms than the 1950s. Statistical Abstracts of the United States, http://www.census.gov/ prod/www/abs/statab1951-1994.htm. Despite these numbers, it is difficult to be conclusive about firm creation in these years.

17 e.g., Raghuram G. Rajan \& Luigi Zingales, "The Great Reversals: The Politics of Financial Development in the Twentieth Century," 69 J. Fin. Econ. 5 (2003). 
There doesn't appear, at least according to this chart, to be any relationship at all, and when we plot the two datasets on a scatter plot, no correlation emerges. (A similar chart dating to 1960 appears in the appendix.) This could mean one of two things. First, there might simply be no relationship between the number of new establishments started in a year and their subsequent success rates, whether success is counted as survival past a certain age, employment and revenue growth, or, eventually, sufficient size to make the Fortune list. Or, we may be too close in time to tell any relationship between these numbers in the period since 1977; in that case, we could need more data down the road.

Most likely, of course, we simply can't tell one way or the other. In fact, if we look at five-year survival rates for any given year's crop of new firms, a remarkably consistent pattern emerges.

Figure 5

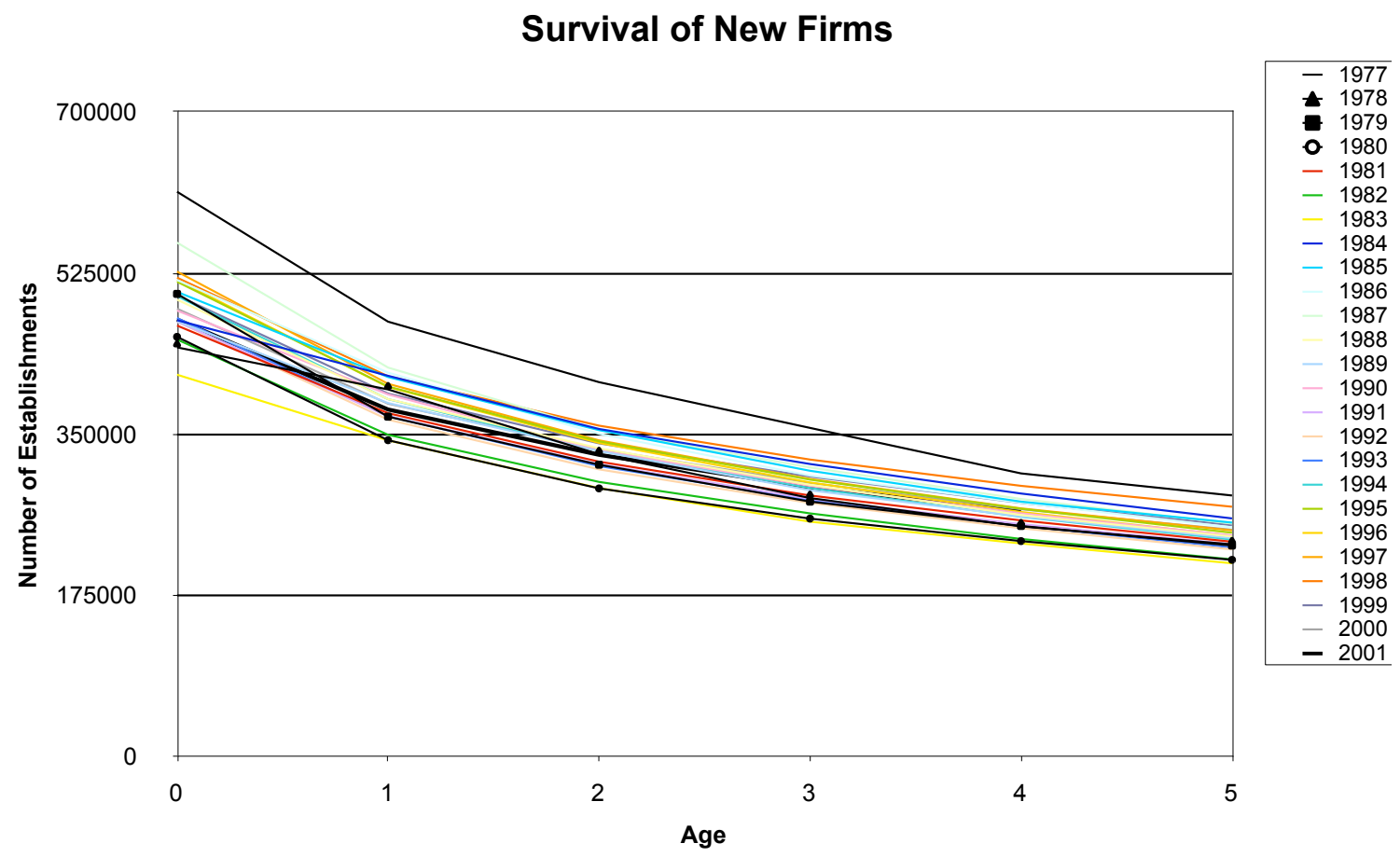

Source: Author's calculations from Census Bureau, Business Dynamics Statistics, Firm Age Database, http://www.ces.census.gov/index.php/bds/bds_database_list. 
This pattern is, initially, quite surprising. For each year, an average of 48-49 percent of new firms survive to age five, and the line for each year is very similar: sharp drops in years one and two, with a flattening in years three to five. ${ }^{18}$ But this makes sense when we consider that there is remarkable consistency from year to year in the number of new firms and establishments that Americans start.

It doesn't appear, then, that we can tell much about a given year based on the number of new firms and their survival-Fortune $\mathbf{5 0 0}$ foundings are just as good an indicator. ${ }^{19}$ Yet it's not entirely clear that we can really infer that a particular year was "good" or "bad" for firm formation based on how many Fortune 500 companies it eventually produced. Was 1959, claiming four Fortune firms, better for new companies than 1923 (three), despite the vast differences between the decades? There is really no way, using these data or really any set of strictly quantitative data, that we can say.

That said, there is wide variability across different industries, different firms, and the quality of survival-simply surviving to age five may say nothing about the firm's actual health. If we drilled down and pulled the numbers apart, we would likely find a high level of churn. ${ }^{20}$ Economist Arnold Harberger, in attempting to capture this paradox, has said that while we usually envision economic growth as akin to yeast, rising evenly, it much more resembles mushrooms-some firms and sectors racing ahead, others falling behind, with the actors and their roles changing each decade, if not each year. ${ }^{21}$

Canvassing the histories of Fortune 500 companies provides a similar lesson in messy capitalism: these firms, notwithstanding their size and perceived sluggishness, are not the Imperial Walkers of Star Wars. There is so much churn and turnover, combination and recombination occurring at any given time in the American economy, that it's often difficult to trace the effects of recessions or bear markets on any one company. Within one company, moreover, there will often be multiple changes of business as management moves from opportunity to

\footnotetext{
18 These numbers are in line with other research. e.g., Amy E. Knaup \& Merissa C. Piazza, "Business Employment Dynamics Data: Survival and Longevity," II, Monthly Labor Review, September 2007, at 3; Brian Headd \& Bruce Kirchhoff, "Small Business Growth: Searching for Stylized Facts," U.S. Small Business Administration, Office of Advocacy Working Paper, October 2007.

19 The longer a firm survives, moreover, the higher its probability of subsequent survival. e.g., Amy E. Knaup \& Merissa C. Piazza, "Business Employment Dynamics Data: Survival and Longevity," II, Monthly Labor Review, September 2007, at 3.

20 e.g., Amy E. Knaup, "Survival and Longevity in the Business Employment Dynamics Data," Monthly Labor Review, May 2005, at 50, 52 ("A closer look at the growth of the birth cohort reveals a wide variation in the growth of employment in each sector, in contrast to the fairly stable measures of establishment survival across sectors."); Amy E. Knaup \& Merissa C. Piazza, "Business Employment Dynamics Data: Survival and Longevity," II, Monthly Labor Review, September 2007, at 3.

${ }^{21}$ Arnold Harberger, "A Vision of the Growth Process," 88 Am. Econ. Rev. 1 (March 1998).
} 
opportunity. FirstEnergy, for example (\#194 on the 2009 list), comprises seven different companies that eventually came together, the earliest dating to 1930. Another, MeadWestvaco (\#365), identifies its first ancestor as starting up in 1846. Our largest companies are full of these types of stories and, perhaps paradoxically, reinforce the general nature of the American economy: messiness. To make an analogical stretch, the U.S. economy evolves much as an organism or ecosystem does-through the constant combination and recombination of new and existing ideas and companies, the sum of which generates economic growth and progress.

Given this narrative, and following from the observation that the 1950s appeared to mark the zenith of bureaucratic capitalism, what can we say about the decades closer to our own time? The spikes in the 1960s and 1980s run together with the story of the American economy's entrepreneurial rebirth. ${ }^{22}$ Rather than dating this rebirth, as is usually done, to 1980 , however, it appears that the wave of companies that have risen to dominance today began to pop up during the 1960s, particularly the latter part of the decade.

Figure 6

Fortune $\mathbf{5 0 0}$ foundings, with Recessions and Bear Markets [combined] (shaded areas)

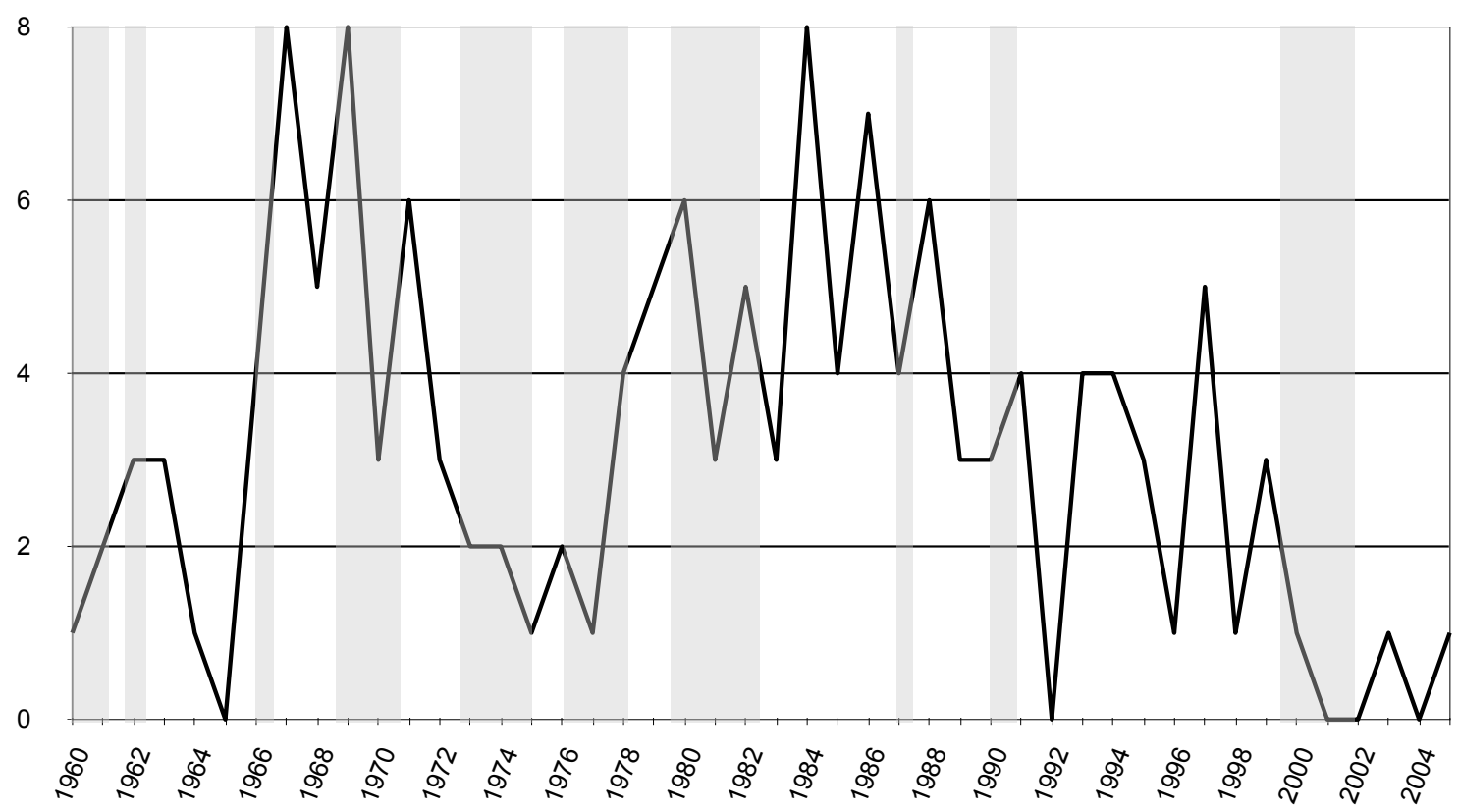

Source: Fortune 500, author's calculations.

${ }^{22}$ e.g., Carl J. Schramm, The Entrepreneurial Imperative, (2006). 
Familiar names date from the late 1960s: Quest Diagnostics (1967); Intel (1968); and Advanced Micro Devices (1969). The 1970s saw the founding of, inter alia, Charles Schwab (1971); Microsoft (1975); Home Depot (1978); and Micron Technology (1978). The entrepreneurial wave continued into the 1980s and, as a result of the rise of new types of industries (Amgen, 1980; Dell, 1984; Cisco Systems, 1984; Staples, 1986), and the renewal of old ones (Valero Energy, 1980; Verizon, 1983; Capital One, 1988; Express Scripts, 1986), forty-nine companies on the 2009 Fortune 500 list date to that decade. ${ }^{23}$

Looking at Figure 6, and recalling that over half of the entire list was founded during a recession and/or bear market, we might be tempted to again conjecture that business cycles don't matter to entrepreneurs. Talk to an entrepreneur and you will quickly see that they often act on an urge or a hunch indifferent to the prevailing economic winds. Indeed, a downturn might actually act as an extra spur to founding a new company, if the founders perceive that their prospective competition might be weakened. And when we look at comparative job creation numbers, we can certainly see that startups demonstrate a much less variable response to business cycles than existing firms.

Figure 7

Job Creation, Entire Economy and from Startups, Showing Recessions

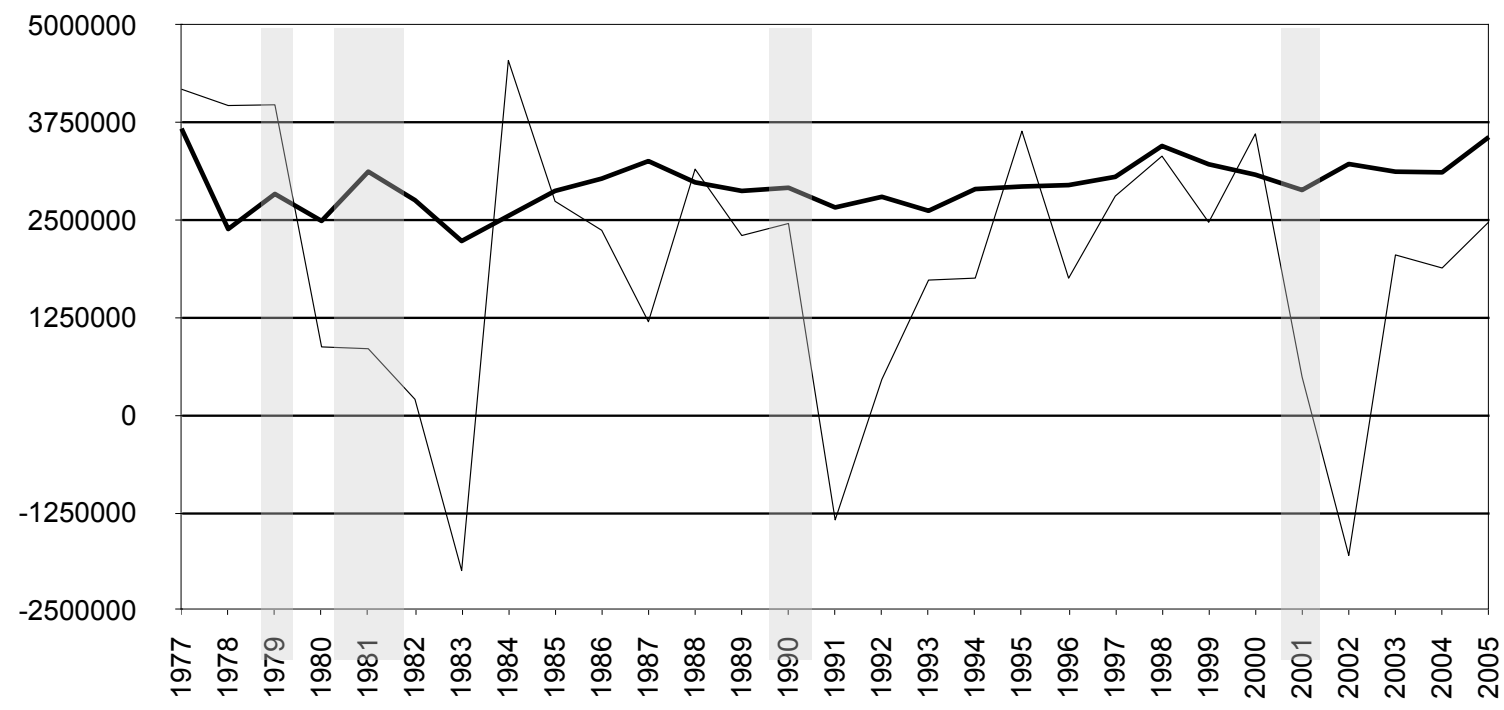

- Net Job Creation, U.S. Economy — Startups Job Creation

Source: Census Bureau, Business Dynamics Statistics, http://www.ces.census.gov/index.php/bds/bds_database_list.

23 The late 1960s was also the time when intangible capital began to catch and, in the 1970s and 1980 s, pass tangible capital in terms of relative shares of the economy. Dominique Foray, The Economics of Knowledge, 22 (2004). 
Figure 8

Startups, and Economy sans Startups

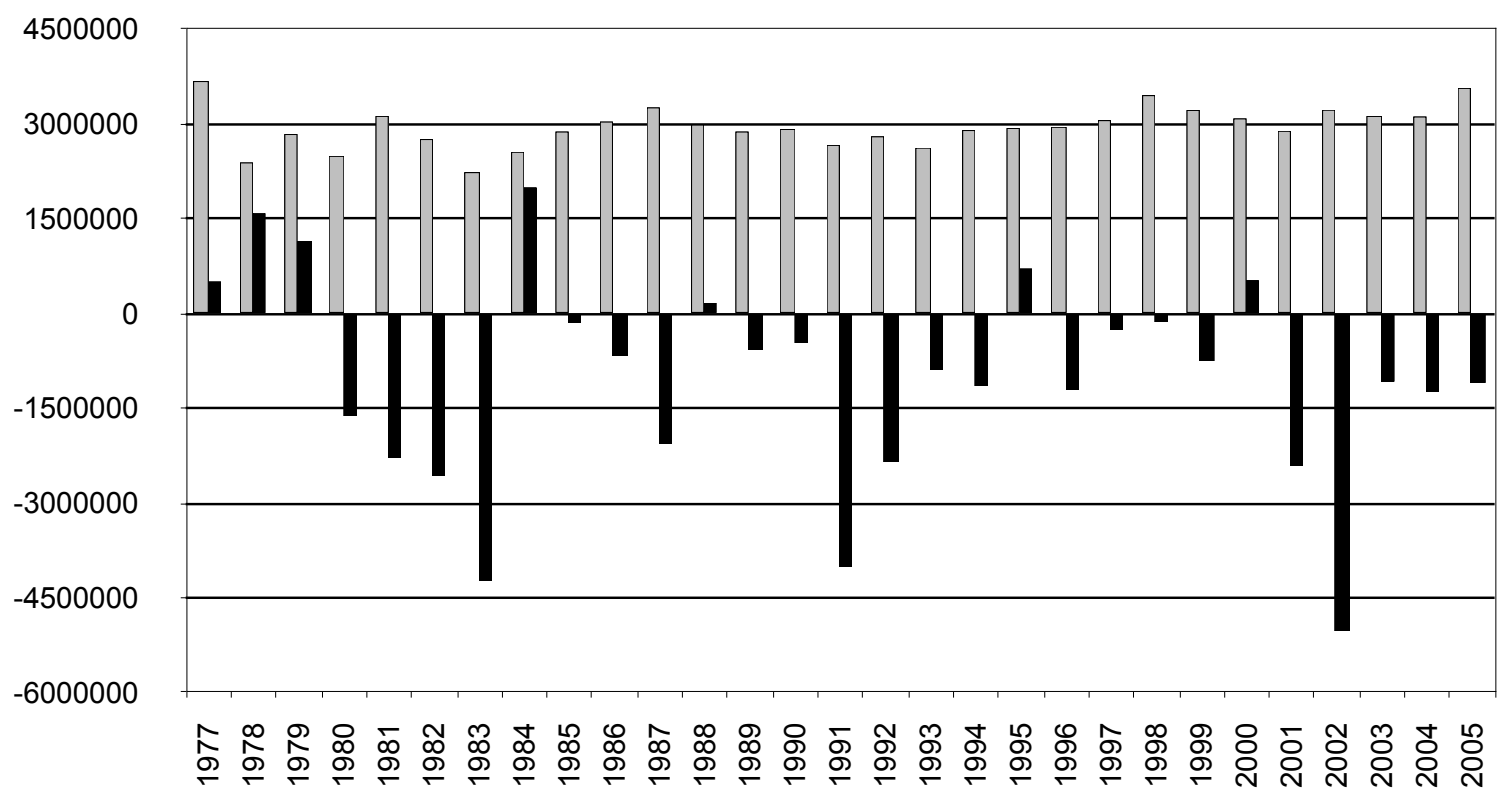

$\square$ Startup Job Creation $\square$ Net Job Creation for Economy, Absent Startups

Source: Census Bureau, Business Dynamics Statistics, http://www.ces.census.gov/index,php/bds/bds_database_list.

\section{Trends in Today's Economy}

The most recent recession before the current downturn, that of 2001-and the accompanying bear market of 2000-02-illustrates some potentially interesting trends. As noted, the companies included on the Inc. 500 list are, on average, six to seven years old. This makes sense: young companies are simply more likely to grow at the astronomical rates (four-digit revenue growth for three years) necessary for inclusion on the list. Thus, most of the Inc. firms that were founded during a recession or bear market began in the 2000-02 period. Several of the foregoing charts, particularly Figures 2 and 8 , as well as the charts in the appendix, seem to indicate that the recession and bear market earlier this decade didn't have much of an impact on new business formation and related jobs creation-especially compared to prior recessions. ${ }^{24}$

\footnotetext{
24 The birth rate of new firms also appears to be a reliable business cycle predictor, falling months before a recession sets in, and rising before it officially ends. e.g., Akbar Sadeghi, "The Births and Deaths of Business Establishments in the United States," Monthly Labor Review, December 2008 , at 3. Sadeghi's research also raises an important question as to the future of new firm creation. He shows that over the past few years, even as firm births have increased, there has been slowing employment creation from such births, due to the decreasing average size of new firms (and, evidently, rising productivity). While on one level this is not surprising (anecdotal evidence has pointed toward the lessening need for capital and employees in new firms, particularly in services), it may also suggest a Red Queen effect—we need more and more new firms to compensate for their shrinking employment size. Further research is required.
} 
It is tempting to read these signs as suggestions that new firm formation now represents the optimal countercyclical economic policy; as mentioned, there are certainly good reasons for individuals to start new companies during a downturn. The link, however, between new firms and aggregate economic performance is not so straightforward. For one thing, some evidence indicates that the jobs created by startups follow a U-shaped curve-generating jobs immediately in their first year, having a negative impact on jobs in years three to five, followed by a more durable positive impact on job creation. ${ }^{25}$ Even the companies on the Inc. 500 list must demonstrate sustained growth over several years. Furthermore, the median employment size of the 2008 Inc. firms is 48a handful are quite large and more will continue to grow larger, but most of them will remain small in terms of job creation. Since 2001, the average size of new firms has fallen by two employees, from six to four. These facts raise questions about the extent to which new companies created in 2008 and 2009 will pull the U.S. economy out of recession.

Yet, for a variety of reasons, such questions are a bit misleading. First, an individual or team of individuals doesn't start a company as an explicit attempt to help the country combat recession. Their motivation is either a good idea or simply a way to beat unemployment-they founded their firm to start building their future. Because the patterns of job expansion and contraction in established companies often amount to a net gain of zero, many people see starting a company-especially amid a recession-as a way to take their future into their own hands. Their objective isn't often scale growth (let alone the Fortune or Inc. lists). As we saw, it's probably impossible to predict the caliber of a given year's new firms. In times of recession, the important contribution of such new firmsregardless of their eventual fate-comes in their immediate positive impact on job creation. As we well know today, job creation is economic policy's top priority.

Second, the benefits of new firm formation are generally recognized to extend beyond job creation. New companies may come into existence to commercialize a new innovation, and they may be more productive than existing firms, thus driving economic growth. Startups may also remain small yet have a hugely positive impact on innovation and job creation in other companies and industries.

\footnotetext{
25 e.g., Michael Fritsch \& Pamela Mueller, "Effects of New Business Formation on Regional Development over Time," 38 Regional Studies 961 (Nov. 2004); C. Mirjam van Praag \& Peter H. Versloot, "What is the Value of Entrepreneurship? A Review of Recent Research," 29 Small Bus. Econ. 351 (Dec. 2007).
} 
Third, the nature of the American economy may be changing such that new firms do play an increasingly important role in digging out of recessions. The overriding consideration here is that the U.S. economy is now dominated, not just by service-oriented businesses, ${ }^{26}$ but by highly innovative services reshaping the pattern of economic activity. An innovative service may, in many minds, conjure up images of high-technology companies, and the Inc. list does include a fair share of information technology and software firms. But there is also a seemingly infinite variety of ways to innovate even in well-established sectors like food and retail.

The great lesson of this analysis is not that we should take heart in the knowledge that the next generation of Fortune 500 firms are likely being born during this recession. As in most other years, 2008 and 2009 will each produce anywhere from 400,000 to 700,000 startups. Many will fail, some will limp along, and many will survive and thrive. A tiny number may turn out to be among the largest companies of 2020 or 2030. A few hundred will show up on the Inc. 500 list in a few years (it is noteworthy that each of the last five recessions, dating to 1973 , has produced high-growth firms).

But, despite the pain of the current recession, there is reason for hope-good things do grow out of recessions. More importantly, new firm formation represents two unqualifiedly positive things. Hundreds of thousands of individuals do not wait for others to ease their economic pain-they create jobs for themselves and others. Young firms, moreover, frequently add jobs and generate innovations well out of the mainstream. When a large, established company announces deep layoffs, it necessarily makes front-page news. When two or three dozen young firms hire four, six, or eight people at a time for several years, it mostly goes unnoticed. Only when they reach sufficient collective size do they begin to appear in the public consciousness, even though they have been regenerating the economy for several years. Every generation of startups is, often invisibly, both a renewal and restructuring of the economy.

\footnotetext{
${ }^{26}$ Services, despite claims to the contrary, have always played a hugely important economic role in the United States.
} 


\section{APPENDIX}

Figure 9

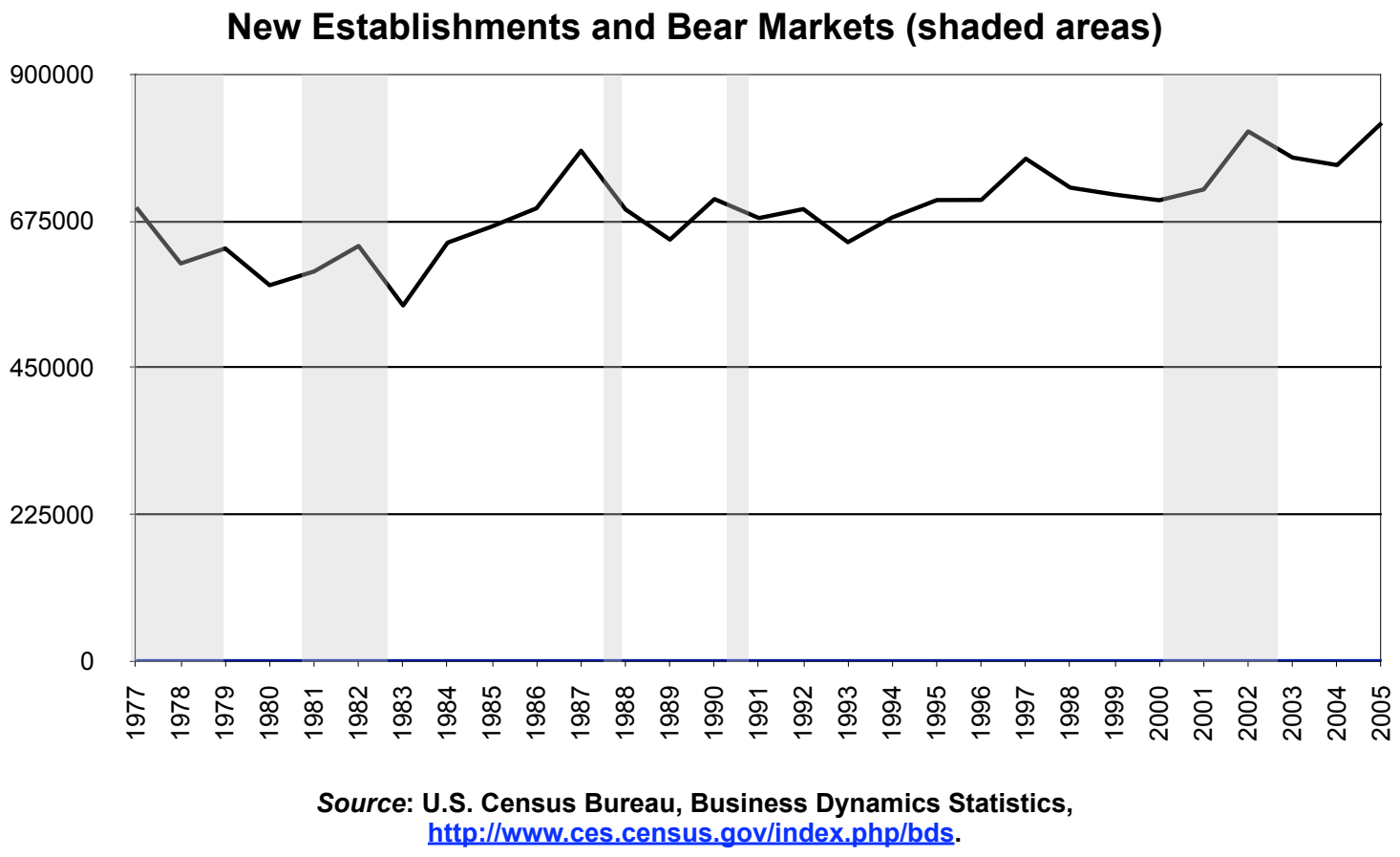

Figure 10

Establishment Entry Rate and Bear Markets (shaded areas)

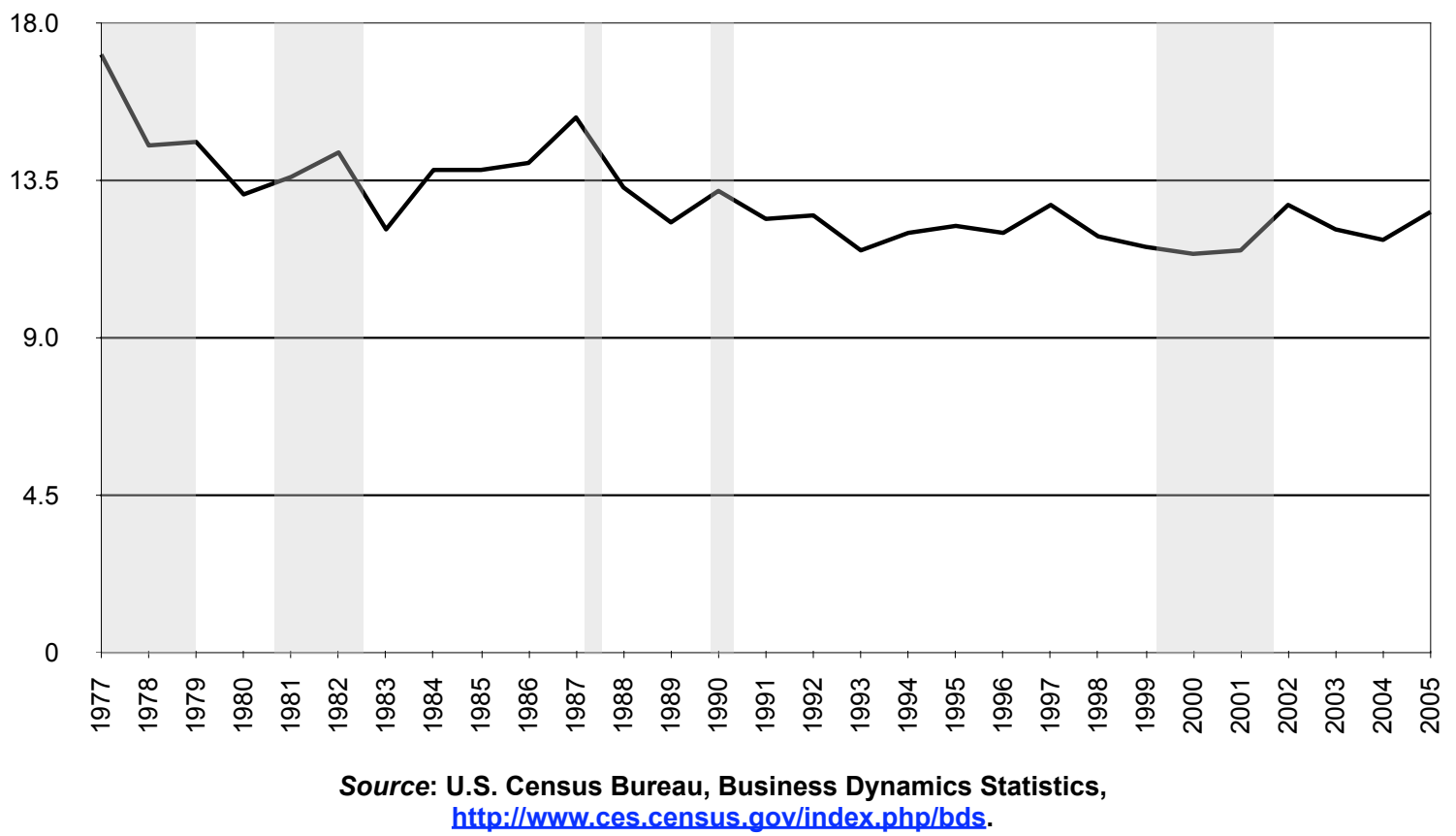


Figure 11

Establishment Entry Rate and Recessions (shaded areas)

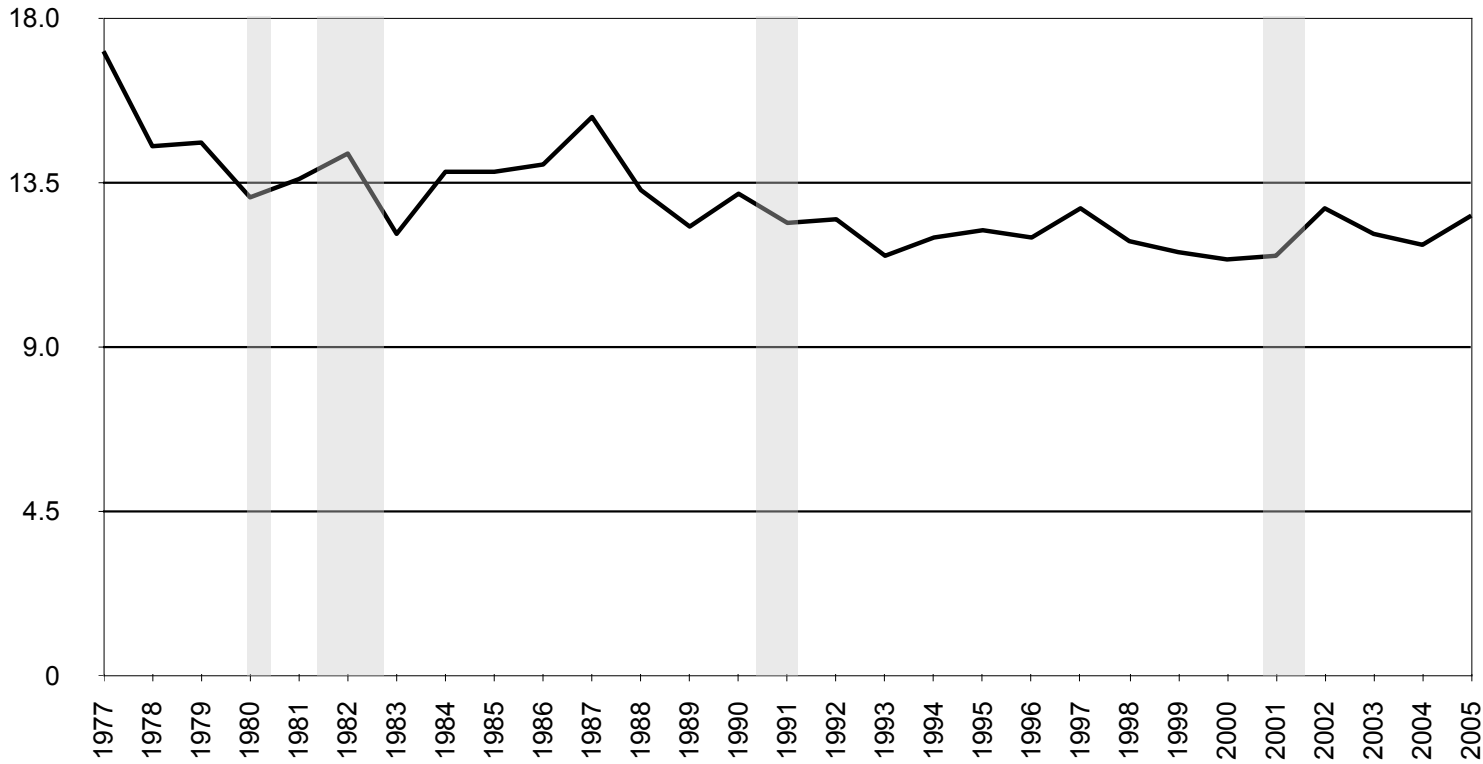

Source: U.S. Census Bureau, Business Dynamics Statistics, http://www.ces.census.gov/index.php/bds.

Figure 12

\section{Business Formation and Fortune 500 Foundings (shaded areas)}

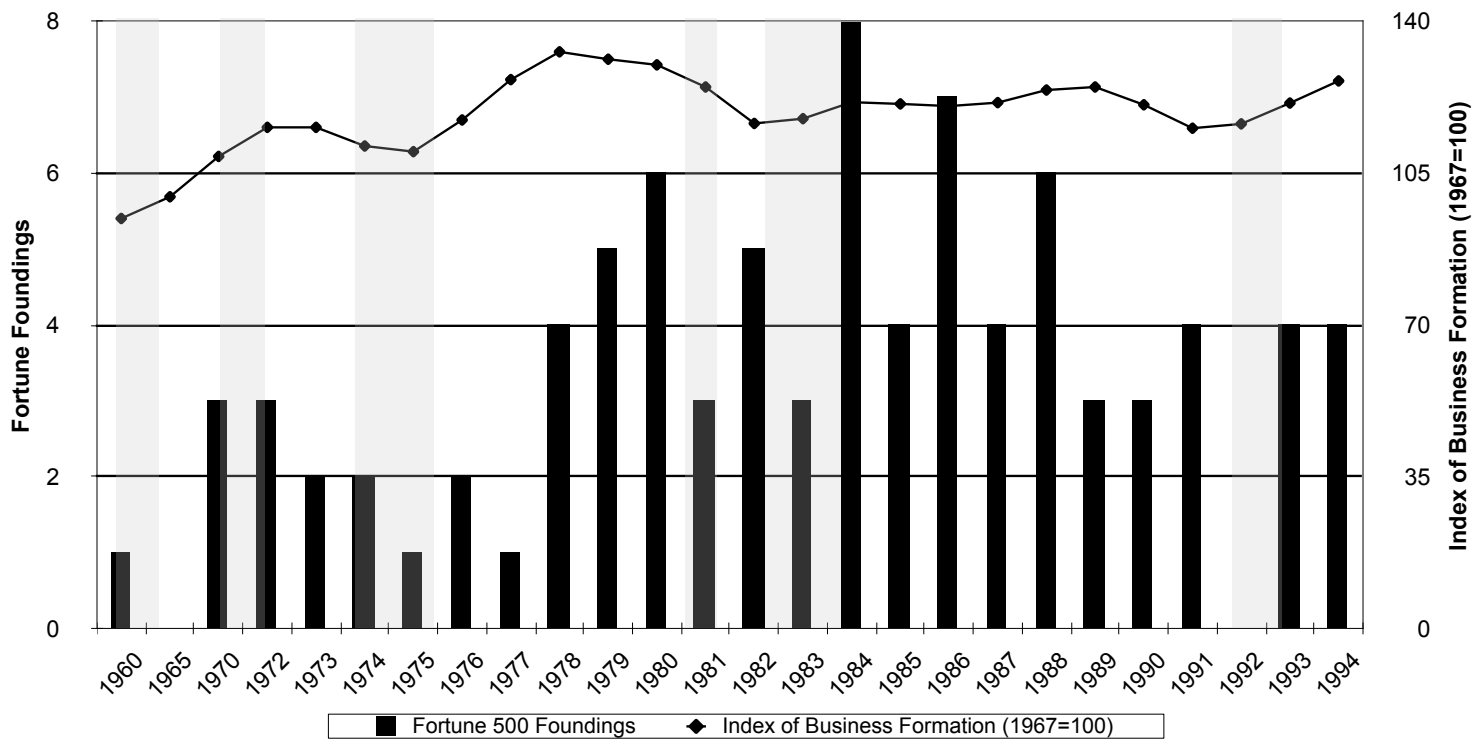

Sources: 1980 Statistical Abstract, Table 971, p. 576; 1994 Statistical Abstract, Table 846, p. 547; 1995 Statistical Abstract Table 860, p.551; 2000 Statistical Abstract Table 875, http://www,census.gov/prod/www/abs/statab.html. 
Figure 13

Firm Births and Productivity

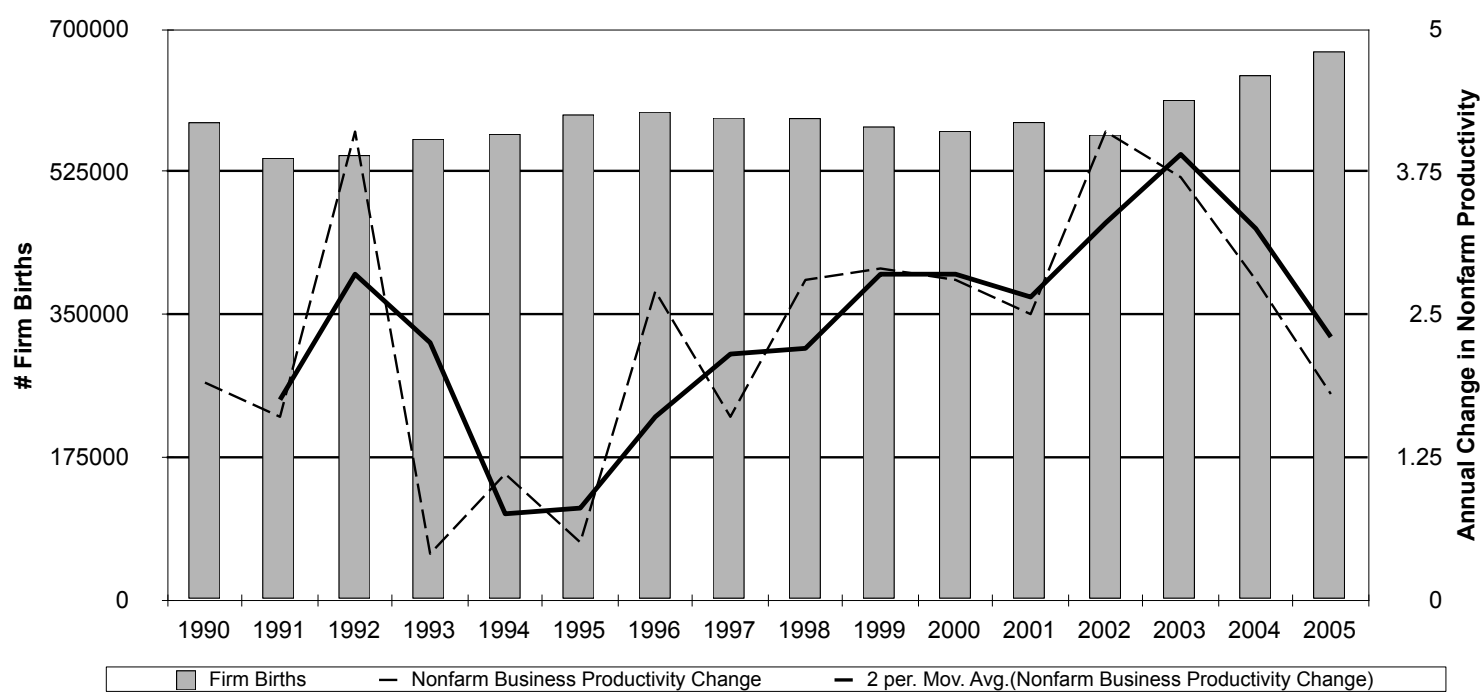

Source: U.S. Census Bureau, Statistics of U.S. Business, http://www.census.gov/csd/susb/susbdyn.htm;

Council of Economic Advisers, 2009 Economic Report of the President, Table B-50, http://www.gpoaccess.gov/eop/tables09.html.

Figure 14

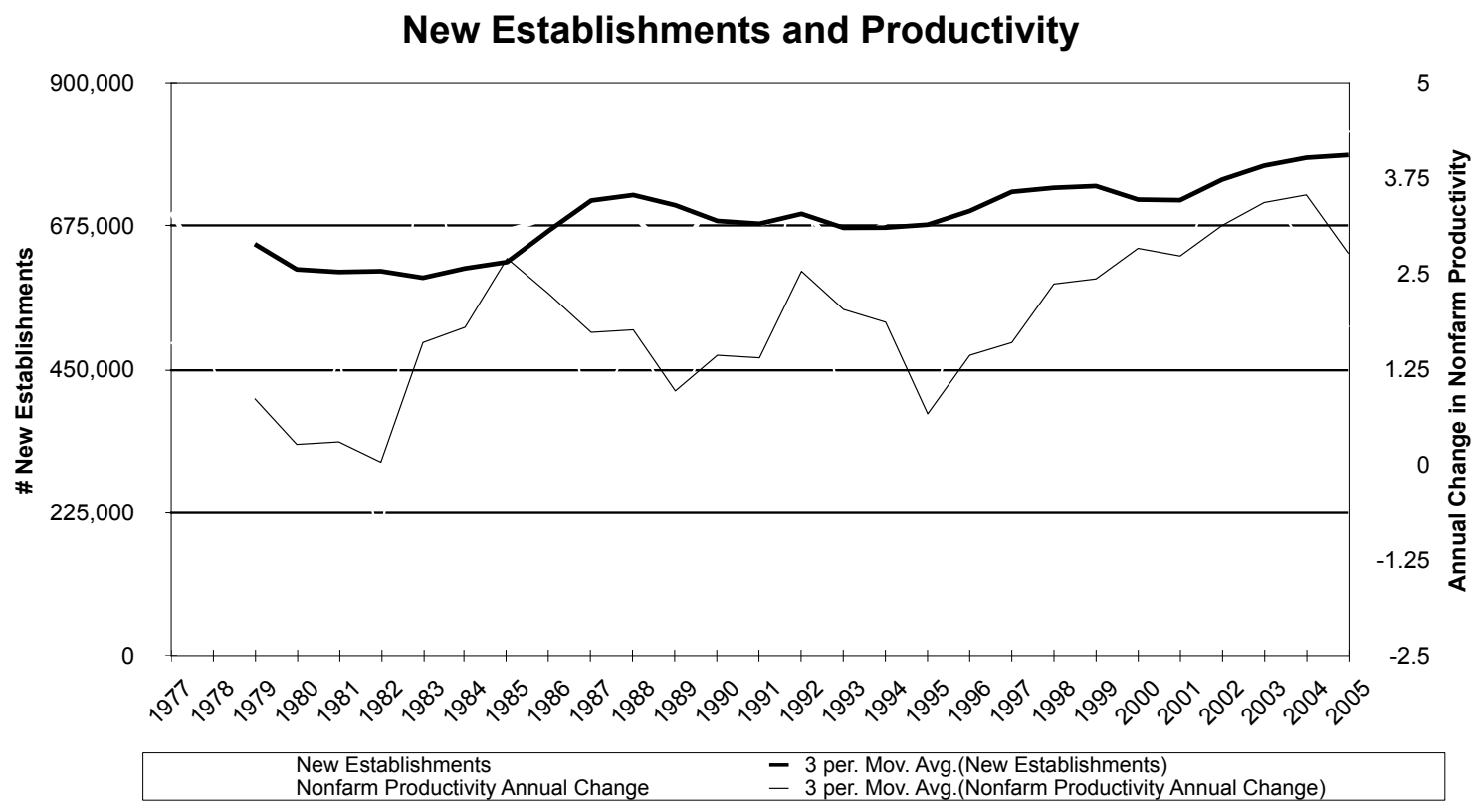

Sources: U.S. Census Bureau, Business Dynamics Statistics, http://www.ces.census.gov/index.php/bds;

Council of Economic Advisers, 2009 Economic Report of the President, Table B-50, http://www.gpoaccess.gov/eop/tables 09.html. 
Figure 15

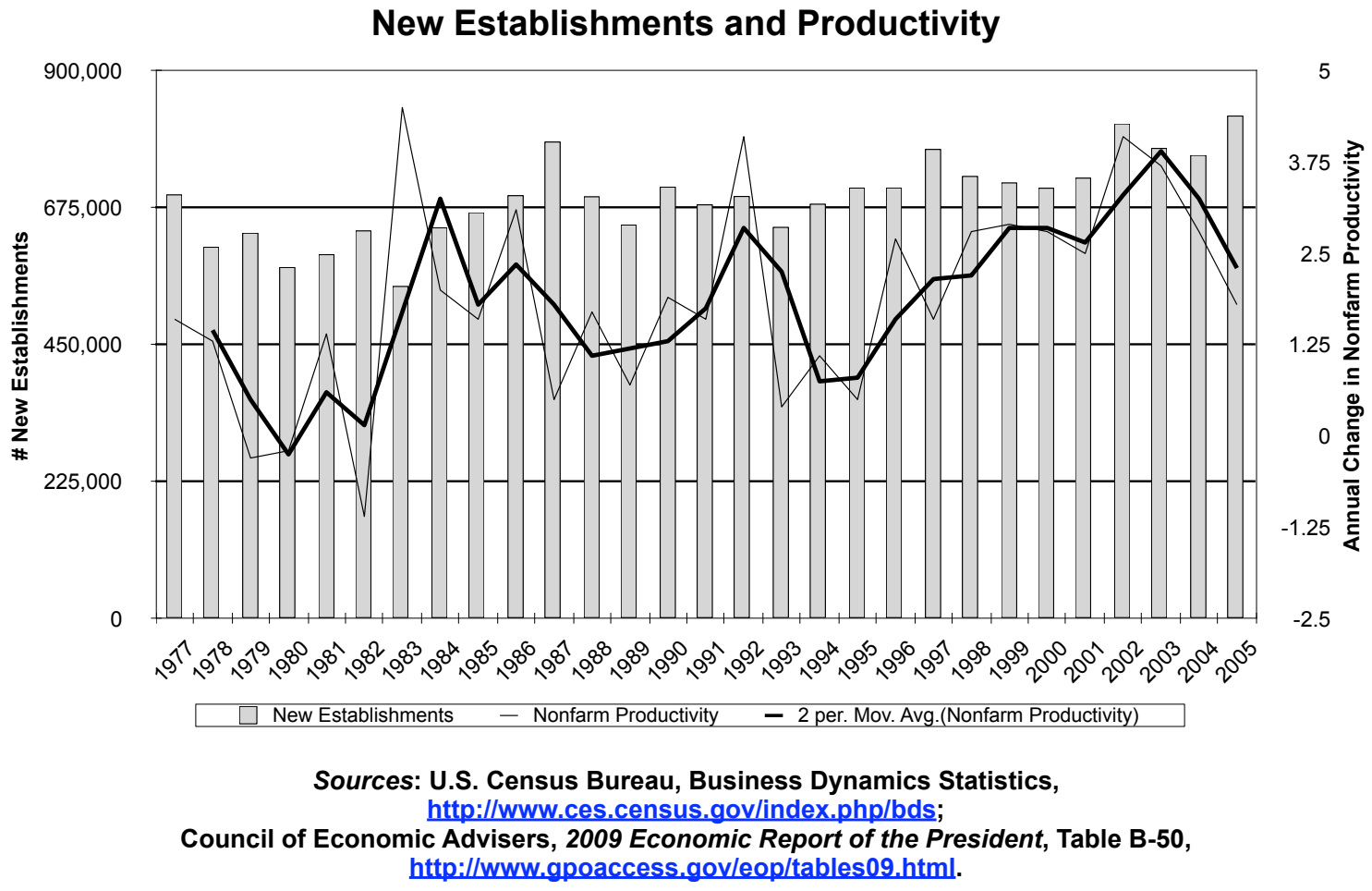

